\title{
Coming in from the cold: potential microbial threats from the terrestrial cryosphere
}

\author{
Arwyn Edwards ${ }^{1,2 *}$ \\ ${ }^{1}$ Institute of Biological, Environmental and Rural Sciences, Aberystwyth University, Aberystwyth, UK, ${ }^{2}$ Interdisciplinary Centre \\ for Environmental Microbiology, Aberystwyth University, Aberystwyth, UK
}

Keywords: cryosphere, emerging infectious diseases, genome recycling, viruses, synthetic biology

"From disease I had little to fear. Antarctica is a paradise in that respect. It is the germless continent." Richard E. Byrd (1938)

The terrestrial cryosphere includes $>198,000$ glaciers and three ice sheets (Pfeffer et al., 2014). The paradigm of cryospheric environments as "germless continents" (Byrd, 1938) has shifted to ecosystems (Kohshima, 1984; Hodson et al., 2008). Indeed, the terrestrial cryosphere constitutes a "forgotten biome" (Anesio and Laybourn-Parry, 2012) with microbial processes influencing the fundamental dynamics of glacial systems (Edwards et al., 2014).

Nevertheless, in terms of genomic diversity, glacial environments are virtual terra incognita. Recent calculations indicate glacial ice harbors ca. $1 \times 10^{29}$ cells worldwide, and ca. $4 \times 10^{21}$ cells are eluted by ice melt from non-Antarctic glacial systems annually (Irvine-Fynn and Edwards, 2013). Therefore, it is clear that glacial systems are major reservoirs of microbial genomic diversity.

If I adopt a "colicentric" view of microbial genomes by crudely assuming that each bacterial or archaeal cell's genome is in the order of $4.6 \times 10^{6}$ base pairs in size, a microbial cell budget of a High Arctic glacier surface (Irvine-Fynn et al., 2012) reveals an aeolian import of $1.9 \times 10^{14} \mathrm{bp}$ $\mathrm{m}^{2} \mathrm{~h}^{-1}$ coupled with a glaciofluvial export of $4.4 \times 10^{13} \mathrm{bp} \mathrm{m}^{2} \mathrm{~h}^{-1}$ which leads to a net storage of $3.5 \times 10^{14} \mathrm{bp} \mathrm{m}^{2} \mathrm{~h}^{-1}$ under typical summer conditions. Yet I am only aware of published high-throughput DNA sequencing datasets from less than 30 of the 198,000 glaciers (Pfeffer et al., 2014). Temporal changes in glacial diversity are even less well studied (excepting Hell et al., 2013; Maccario et al., 2014; Stibal et al., 2014). Since most studies sequence marker genes, metagenomic, and phylogenomic coverage is sparse (excepting Simon et al., 2009; Edwards et al., 2013b), and the potential for lateral gene transfer unexplored. Therefore, while glacial systems are potentially massive repositories of genomic diversity they represent virtually unexplored sequence space.

Here I will focus upon the role of glacial systems as reservoirs of genomic diversity in one particular form: the accumulation, storage and release of pathogens. While the notion that mysterious entities inimical to humanity survive in ice is almost cliché in science fiction, the hypothesis that glacial systems act as "genome recyclers" was stated a decade ago (Rogers et al., 2004; Castello and Rogers, 2005; Priscu et al., 2007) and has garnered tacit empirical support. Nonetheless, the role of glacial systems as reservoirs of pathogens of humans, other animals and plants is the most "frequently asked question" in the author's experience of engaging with stakeholders, the general public and scientists in other fields, not to mention deskbound reviewers of risk assessments. With the caveat that cryospheric microbial associated morbidity and mortality is hitherto confined to anecdotal reports of snow algae-associated diarrhea (Fiore et al., 1997) and that there are many pressing priorities in the realm of emerging infectious diseases, it appears that changes in the

Edwards A (2015) Coming in from the cold: potential microbial threats from

the terrestrial cryosphere.

Front. Earth Sci. 3:12.

doi: $10.3389 /$ feart.2015.00012

Abbreviations: AIV, Avian Influenza Virus; T-RFLP, Terminal Restriction Fragment Length Polymorphism; VLP, Virus Like Particle. 
terrestrial cryosphere potentiate a range of fungal, bacterial and viral threats to human, plant and animal health.

\section{Fungal Threats}

The ecology of fungi in glacial systems is poorly explored, although yeast are readily isolated from a variety of habitats (Turchetti et al., 2008). Beyond this, most phylotypes revealed by T-RFLP of cryoconite on Svalbard glaciers were not cultured from the same samples, implying that glacier surfaces harbor a poorly-documented and as yet uncultured fungal community (Edwards et al., 2013a).

Three potential threats are evaluated from glacier fungi. The first of these is the predominance of Cryptococcus basidiomycete yeasts in culture surveys of glacial ice (Turchetti et al., 2015). As a genus, Cryptococcus is split between opportunistic pathogens of immunocompromised humans and environmental yeasts (Chen et al., 2014; Turchetti et al., 2015). However, while the niche represented by immunocompromised humans is expanding (Groll and Walsh, 2001), adaptation from cold to warm environments may present a significant barrier for basidiomycete yeast (Van Uden, 1984), precluding threats from cryospheric Cryptococcus. A second category of threat is represented by polyextremotolerant fungi, principally black yeast. Gostincar et al. (2011) argue that the extraordinary phenotypic plasticity of these organisms, which permits their survival in natural extreme environments including glaciers (Zalar et al., 2008) also permit them to survive in human-associated extreme environments such as the built environment and the human host itself. Both environments are "extreme" in terms of their nutrient limitation, $\mathrm{pH}$, osmotic and oxidative stresses, so adaptation to natural extremes could facilitate spill-over to human-associated habitats. Hitherto, there have been case reports of opportunistic infections from Aureobasidium pullulans (Salkin et al., 1986; Bolignano and Criseo, 2003) which lend credence to this theory.

"Green and red" fungal pathogens represent a final category affecting plant and animal health respectively and hence food security and biodiversity (Fisher et al., 2012). Plant associated fungi have been recovered from glaciers. In particular, an aeroaquatic-endophytic life cycle for Helotiales and Pleosporales sp. where ascomycete fungi inoculated onto glacier surfaces in aeolian plant debris colonize cryoconite and produce aeroaquatic spores well-suited to fluvial dispersal to pursue an endophytic lifestyle in forefield vegetation (Edwards et al., 2013a) illustrate the concept of glaciers as "genome recyclers." Recovery of endophytes from Svalbard cryoconite most closely related to fungal clones from the grass clothing of the Neolithic iceman "Ötzi" (Genbank X88771) further evidence the storage of plantassociated fungi in glacial environments. Furthermore, the same study revealed isolates of Ascochyta rabiei (EU167600), which causes foliar leaf diseases of agricultural crops and Theleobolus sp. (JQ692167), previously associated with Antarctic skua mortality (Leotta et al., 2002). Clearly, while adaptations to cold environments may preclude many glacier fungi from affecting mammalian hosts, impacts on plant and animal health must be considered, especially as these would affect ecosystem and food security.

\section{Bacterial Threats}

Even in extremis, glacial ice is a bacterial habitat (e.g., Abyzov et al., 1998). The potential for pathogenic bacteria to be transmitted via the fecal-oral route in glacial environments exists. An early report (Dancer et al., 1997) revealed a range of culturable coliforms in a variety of samples from the Canadian Arctic archipelago which included glacial ice up to 2000 years old. Approximately a third of the coliform isolates from glacial ice resisted ampicillin. More recently, the potential for pathogens from feces deposited by recreational climbers in the Denali National park to survive englacial transit has been examined (Goodwin et al., 2012). Culture revealed a range of thermotolerant coliforms, Escherichia coli and fecal streptococci in meltwaters collected over several seasons. Furthermore, numerical flow modeling of the transfer of the two metric tons of feces from camps high on Kahiltna glacier suggested that feces could be advected to the surface of the glacier at lower elevations within a century. While the risk demographic for fecal-oral transmission is curtailed to visitors drinking untreated water, this population is expanding rapidly as the popularity of guided ascents and "last chance" polar tourism increases (Lemelin et al., 2010; Goodwin et al., 2012).

A further dimension of threat to human health from bacteria in glacial systems is presented by the abundance of antibiotic resistance determinants in samples of glacial ice and snow from a global range of glacial systems. Resistance genes for clinically_and agriculturally-important antibiotics such as chloramphenicol, beta-lactams, streptomycin and tetracycline have been quantified by workers using real-time PCR (Ushida et al., 2010; Segawa et al., 2013). Furthermore, evolutionarily divergent but functional beta-lactamases have been cloned from geographically remote Alaskan soils by functional metagenomics (Allen et al., 2009). It has been presumed that migratory birds and airborne bacteria are responsible for distributing these genes into these presumably "pristine" environments (Segawa et al., 2013). The limited distribution of antibiotic resistance genes in Antarctic ice (Segawa et al., 2013) indicates that the removal of human waste, as mandated within Annex III of the Antarctic Treaty environmental protocol may be an important biosecurity measure in this regard (Hughes and Nobbs, 2004).

While antibiotic resistance genes are currently multifariously prevalent in habitats proximal to human populations, the potential for glacial systems to act as a reservoir of antibiotic resistance genes in a future where antibiotic usage has been curtailed as a precaution is analogous to the contemporary role of glacial systems in storing and releasing legacy pollutants such as persistent organic pollutants and radionuclides (Tieber et al., 2009; Hodson, 2014).

\section{Viral Threats}

Viruses in glacial systems are abundant and viral-induced bacterial mortality is a potent top-down control on productivity in glacial systems (Anesio and Bellas, 2011). Viruses and their genetic material present distinct threats. The potential for viruses of eukaryotes to persist in the terrestrial cryosphere is the subject 
of high profile investigations. Researchers attempted, with varying success and extent of biosecurity protocol, to recover material from 1918 pandemic influenza victims entombed within frozen ground. The most successful attempt attempt examined the remains of inhabitants of Brevig mission in Alaska. Initial attempts to cultivate virus in the 1950s failed, perhaps fortunately, given photographs of researchers mouth-pipetting samples to inoculate eggs (Kolata, 2001). The later recovery of viral RNA lpermitted the generation of H1N1 influenza chimeras expressing neuraminidase derived from Brevig samples (Qi et al., 2009). The recovery of viable avian influenza virus (AIV) from Siberian lake ice contaminated by migratory birds (Zhang et al., 2006) and the presence of divergent AIVs within Antarctic penguin populations (Hurt et al., 2014) underscore the potential for cryospheric reservoirs of influenza viruses.

Recent reports of viable giant amoebal-infecting viruses from Siberian permafrost dated to 30,000 years before present raise the prospect that viruses may survive for extended periods in cryospheric environments (Legendre et al., 2014). Nevertheless, it is therefore highly unlikely that viruses persisting in mineralrich matrices such as permafrost soils would represent a viable source of infection. Moreover, poxviral DNA recovered from mummified remains in Siberian permafrost is fragmented to sizes $<2 \mathrm{kbp}$ within 300 years (Biagini et al., 2012) and short amplicons from tobacco mosaic tobomovirus RNA in 35,000 year old Greenland ice (Castello et al., 1999) cast further doubt on the prospect of intact, infectious viral particles persisting in cryospheric environments for prolonged periods of time.

Viral genomic material preserved in cryospheric environments presents a threat by other means. At an estimated $>10^{31}$ bp which requires advanced metaviromic tools to access, the sum of viral genomes, or the global virosphere, represents the most diverse and technically challenging sequence space on Earth (e.g., Suttle, 2005). A predictive understanding of viral genome function and tropism is therefore difficult to attain from sequences. It is against this background that two viral genomes were recovered from 700 year caribou feces preserved in ice patches in the Canadian Arctic recently (Ng et al., 2014). While one RNA virus genome presumed to infect arthropods was partially recovered, reverse genetics approaches permitted the reconstitution of

\section{References}

Abyzov, S. S., Mitskevich, I. N., and Poglazova, M. N. (1998). Microflora of the deep glacier horizons of central Antarctica. Microbiology 67, 451-458.

Allen, H. K., Moe, L. A., Rodbumrer, J., Gaarder, A., and Handelsman, J. (2009). Functional metagenomics reveals diverse beta-lactamases in a remote Alaskan soil. ISME J. 3, 243-251. doi: 10.1038/ismej.2008.86

Anesio, A. M., and Bellas, C. M. (2011). Are low temperature habitats hot spots of microbial evolution driven by viruses? Trends Microbiol. 19, 52-57. doi: 10.1016/j.tim.2010.11.002

Anesio, A. M., and Laybourn-Parry, J. (2012). Glaciers and ice sheets as a biome. Trends Ecol. Evol. 27, 219-225. doi: 10.1016/j.tree.2011.09.012

Biagini, P., Thèves, C., Balaresque, P., Géraut, A., Cannet, C., Keyser, C., et al. (2012). Variola virus in a 300-Year-Old Siberian mummy. N. Engl. J. Med. 367, 2057-2059. doi: 10.1056/NEJMc1208124

Bichaud, L., De Lamballerie, X., Alkan, C., Izri, A., Gould, E. A., and Charrel, R. N. (2014). Arthropods as a source of new RNA viruses. Microb. Pathog. 77, 136-141. doi: 10.1016/j.micpath.2014.09.002 a small DNA viral genome to infect plants under laboratory conditions, although it is thought the virus may have infected fungi, not plants, in nature. Plant viruses can affect food security, and dozens of the 100 of known arboviruses infect humans (Bichaud et al., 2014).

Given the considerable uncertainties surrounding the tropism of viruses from divergent lineages such experiments are audacious. Moreover, no specific biosafety protocols or ethical oversight were reported than the use of locked growth cabinets to house infected plants ( $\mathrm{Ng}$ et al., 2014). At a time when ethics of "gain of function" experiments conducted in strict biosafety conditions for well-known agents such as AIV are hotly debated (Casadevall and Imperiale, 2014) reconstituting enigmatic viruses from ancient samples must be subject to rigorous risk assessment and scrutiny. While the survival of virus particles on centennial timescales in the cryosphere itself is uncertain, as the toolbox of metavirome and synthetic biology researchers grows, laboratory resurrection of enigmatic viruses itself presents a novel microbial threat from the cryosphere.

In summary, the recognition that microbial and viral life forms are abundant in the cryosphere has transformed our appreciation of what were thought to be "germless continents." However, our understanding of cryospheric genomic diversity is cursory. This brief survey identifies a range of potential microbial threats from the cryosphere which require further evaluation as ice melt liberates considerable numbers of microbes. Most urgently I contend that we must ensure that experiments which resurrect enigmatic viruses from the cryosphere are subject to proper and transparent biosafety, biosecurity and ethical governance.

\section{Acknowledgments}

Research into glacier biodiversity in my laboratory is funded by NERC NE/K000942/1 while research into biomedical aspects of glacial systems biology is supported by the Life Sciences National Research Network of Wales and AU iCEM is supported by Higher Education Funding Council for Wales Research Capital Investment. I gratefully acknowledge Dr. Mark O. Martin (https:// twitter.com/markowenmartin) for the concept of "colicentrism."
Bolignano, G., and Criseo, G. (2003). Disseminated nosocomial fungal infection by Aureobasidium pullulans var. melanigenum: a case report. J. Clin. Microbiol. 41, 4483-4485. doi: 10.1128/JCM.41.9.4483-4485.2003

Byrd, R. E. (1938). Alone: The Classic Polar Adventure. Washington, DC: Island Press.

Casadevall, A., and Imperiale, M. J. (2014). Risks and benefits of gainof-function experiments with pathogens of pandemic potential, such as influenza virus: a call for a science-based discussion. mBio 5:e01730-14. doi: 10.1128/mBio.01730-14

Castello, J. D., and Rogers, S. O. (2005). Life in Ancient Ice. Princeton, NJ: Princeton University Press.

Castello, J. D., Rogers, S. O., Starmer, W. T., Catranis, C. M., Ma, L., Bachand, G. D., et al. (1999). Detection of tomato mosaic tobamovirus RNA in ancient glacial ice. Polar Biol. 22, 207-212. doi: 10.1007/s003000050411

Chen, S. C.-A., Meyer, W., and Sorrell, T. C. (2014). Cryptococcus gattii infections. Clin. Microbiol. Rev. 27, 980-1024. doi: 10.1128/CMR.00126-13

Dancer, S. J., Shears, P., and Platt, D. J. (1997). Isolation and characterization of coliforms from glacial ice and water in Canada's High 
Arctic. J. Appl. Microbiol. 82, 597-609. doi: 10.1111/j.1365-2672.1997. tb03590.x

Edwards, A., Douglas, B., Anesio, A. M., Rassner, S. M., Irvine-Fynn, T. D. L., Sattler, B., et al. (2013a). A distinctive fungal community inhabiting cryoconite holes on glaciers in Svalbard. Fungal Ecol. 6, 168-176. doi: 10.1088/17489326/8/3/035003

Edwards, A., Irvine-Fynn, T., Mitchell, A. C., and Rassner, S. M. E. (2014). A germ theory for glacial systems? Wiley Interdiscip. Rev. Water 1, 331-340. doi: $10.1002 /$ wat2.1029

Edwards, A., Pachebat, J. A., Swain, M., Hegarty, M., Hodson, A., Irvine-Fynn, T. D. L., et al. (2013b). A metagenomic snapshot of taxonomic and functional diversity in an alpine glacier cryoconite ecosystem. Environ. Res. Lett. 8:035003. doi: 10.1088/1748-9326/8/3/035003

Fiore, D. C., Mckee, D. D., and Janiga, M. A. (1997). Red snow: is it safe to eat? a pilot study. Wilderness Environ. Med. 8, 94-95. doi: 10.1580/10806032(1997)008[0094:RSIIST]2.3.CO;2

Fisher, M. C., Henk, D. A., Briggs, C. J., Brownstein, J. S., Madoff, L. C., Mccraw, S. L., et al. (2012). Emerging fungal threats to animal, plant and ecosystem health. Nature 484, 186-194. doi: 10.1038/nature10947

Goodwin, K., Loso, M. G., and Braun, M. (2012). Glacial transport of human waste and survival of fecal bacteria on Mt. McKinley's Kahiltna Glacier, Denali National Park, Alaska. Arctic Antarct. Alp. Res. 44, 432-445. doi: 10.1657/19384246-44.4.432

Gostincar, C., Grube, M., and Gunde-Cimerman, N. (2011). Evolution of fungal pathogens in domestic environments? Fungal Biol. 115, 1008-1018. doi: 10.1016/j.funbio.2011.03.004

Groll, A. H., and Walsh, T. J. (2001). Uncommon opportunistic fungi: new nosocomial threats. Clin. Microbiol. Infect. 7, 8-24. doi: 10.1111/j.14690691.2001.tb00005.x

Hell, K., Edwards, A., Zarsky, J., Podmirseg, S. M., Girdwood, S., Pachebat, J. A., et al. (2013). The dynamic bacterial communities of a melting High Arctic glacier snowpack. ISME J. 7, 1814-1826. doi: 10.1038/ismej.2013.51

Hodson, A., Anesio, A. M., Tranter, M., Fountain, A., Osborn, M., Priscu, J., et al. (2008). Glacial ecosystems. Ecol. Monogr. 78, 41-67. doi: 10.1890/07-0187.1

Hodson, A. J. (2014). Understanding the dynamics of black carbon and associated contaminants in glacial systems. Wiley Interdiscip. Rev. Water 1, 141-149. doi: $10.1002 /$ wat2.1016

Hughes, K. A., and Nobbs, S. J. (2004). Long-term survival of human faecal microorganisms on the Antarctic Peninsula. Antarct. Sci. 16, 293-297. doi: 10.1017/S095410200400210X

Hurt, A. C., Vijaykrishna, D., Butler, J., Baas, C., Maurer-Stroh, S., Silva-De-LaFuente, M. C., et al. (2014). Detection of evolutionarily distinct avian influenza a viruses in Antarctica. mBio 5:e1098-14. doi: 10.1128/mBio.01098-14

Irvine-Fynn, T. D. L., and Edwards, A. (2013). A frozen asset: the potential of flow cytometry in constraining the glacial biome. Cytometry A 85, 3-7. doi: 10.1002/cyto.a.22411

Irvine-Fynn, T. D. L., Edwards, A., Newton, S., Langford, H., Rassner, S. M., Telling, J., et al. (2012). Microbial cell budgets of an Arctic glacier surface quantified using flow cytometry. Environ. Microbiol. 14, 2998-3012. doi: 10.1111/j.1462-2920.2012.02876.x

Kohshima, S. (1984). A novel cold-tolerant insect found in a Himalayan glacier. Nature 310, 222-227. doi: $10.1038 / 310225 \mathrm{a} 0$

Kolata, G. (2001). Flu: The Story of the Great Influenza Pandemic of 1918 and the Search for the Virus that Caused it. London: Simon and Schuster.

Legendre, M., Bartoli, J., Shmakova, L., Jeudy, S., Labadie, K., Adrait, A., et al. (2014). Thirty-thousand-year-old distant relative of giant icosahedral DNA viruses with a pandoravirus morphology. Proc. Natl. Acad. Sci. U.S.A. 111, 4274-4279. doi: 10.1073/pnas.1320670111

Lemelin, H., Dawson, J., Stewart, E. J., Maher, P., and Lueck, M. (2010). Lastchance tourism: the boom, doom, and gloom of visiting vanishing destinations. Curr. Issues Tourism 13, 477-493. doi: 10.1080/13683500903406367

Leotta, G. A., Pare, J. A., Sigler, L., Montalti, D., Vigo, G., Petruccelli, M., et al. (2002). Thelebolus microsporus mycelial mats in the trachea of wild brown skua (Catharacta antarctica lonnbergi) and South Polar skua (C. maccormicki) carcasses. J. Wildl. Dis. 38, 443-447. doi: 10.7589/0090-3558-38.2.443

Maccario, L., Vogel, T., and Larose, C. (2014). Potential drivers of microbial community structure and function in Arctic snow. Front. Microbiol. 5:413. doi: $10.3389 /$ fmicb.2014.00413
Ng, T. F. F., Chen, L.-F., Zhou, Y., Shapiro, B., Stiller, M., Heintzman, P. D., et al. (2014). Preservation of viral genomes in 700-y-old caribou feces from a subarctic ice patch. Proc. Natl. Acad. Sci. U.S.A. 111, 16842-16847. doi: 10.1073/pnas.1410429111

Pfeffer, W. T., Arendt, A. A., Bliss, A., Bolch, T., Cogley, J. G., Gardner, A. S., et al. (2014). The Randolph Glacier Inventory: a globally complete inventory of glaciers. J. Glaciol. 60, 537-552. doi: 10.3189/2014JoG13J176

Priscu, J. C., Christner, B. C., Foreman, C. M., and Royston-Bishop, G. (2007). "Biological material in ice cores," in Encyclopaedia of Quaternary Sciences, 2nd Edn., ed S. A. Elias (Elsevier), 1156-1166.

Qi, L., Kash, J. C., Dugan, V. G., Wang, R., Jin, G., Cunningham, R. E., et al. (2009). Role of sialic acid binding specificity of the 1918 Influenza Virus hemagglutinin protein in virulence and pathogenesis for mice. J. Virol. 83, 3754-3761. doi: 10.1128/JVI.02596-08

Rogers, S. O., Starmer, W. T., and Castello, J. D. (2004). Recycling of pathogenic microbes through survival in ice. Med. Hypotheses 63, 773-777. doi: 10.1016/j.mehy.2004.04.004

Salkin, I. F., Martinez, J. A., and Kemna, M. E. (1986). Opportunistic infection of the spleen caused by Aureobasidium pullulans. J. Clin. Microbiol. 23, 828-831.

Segawa, T., Takeuchi, N., Rivera, A., Yamada, A., Yoshimura, Y., Barcaza, G., et al. (2013). Distribution of antibiotic resistance genes in glacier environments. Environ. Microbiol. Reports 5, 127-134. doi: 10.1111/1758-2229. 12011

Simon, C., Wiezer, A., Strittmatter, A. W., and Daniel, R. (2009). Phylogenetic diversity and metabolic potential revealed in a glacier ice metagenome. Appl. Environ. Microbiol. 75, 7519-7526. doi: 10.1128/AEM.00946-09

Stibal, M., Schostag, M., Cameron, K. A., Hansen, L. H., Chandler, D. M., Wadham, J. L., et al. (2014). Different bulk and active bacterial communities in cryoconite from the margin and interior of the Greenland ice sheet. Environ. Microbiol. Rep. 7, 293-300. doi: 10.1111/1758-2229.12246

Suttle, C. A. (2005). Viruses in the sea. Nature 437, 356-361. doi: 10.1038 /nature 04160

Tieber, A., Lettner, H., Bossew, P., Hubmer, A., Sattler, B., and Hofmann, W. (2009). Accumulation of anthropogenic radionuclides in cryoconites on Alpine glaciers. J. Environ. Radioact. 100, 590-598. doi: 10.1016/j.jenvrad.2009. 04.008

Turchetti, B., Buzzini, P., Goretti, M., Branda, E., Diolaiuti, G., D’agata, C., et al. (2008). Psychrophilic yeasts in glacial environments of Alpine glaciers. FEMS Microbiol. Ecol. 63, 73-83. doi: 10.1111/j.1574-6941.2007. 00409.x

Turchetti, B., Selbmann, L., Blanchette, R. A., Di Mauro, S., Marchegiani, E., Zucconi, L., et al. (2015). Cryptococcus vaughanmartinae sp. nov and Cryptococcus onoforri sp. nov.: two new species isolated from worldwide cold environments. Extremophiles 19, 149. doi: 10.1007/s00792-014-0692-3

Ushida, K., Segawa, T., Kohshima, S., Takeuchi, N., Fukui, K., Li, Z., et al. (2010). Application of real-time PCR array to the multiple detection of antibiotic resistant genes in glacier ice samples. J. Gen. Appl. Microbiol. 56, 43-52. doi: 10.2323 /jgam. 56.43

Van Uden, N. (1984). Temperature profiles of yeasts. Advan. Microbial. Physiol. 25, 195-251. doi: 10.1016/S0065-2911(08)60293-3

Zalar, P., Gostincar, C., de Hoog, G., Ursic, V., Sudhadham, M., and GundeCimerman, N. (2008). Redefinition of Aureobasidium pullulans and its varieties. Stud. Mycol. 61, 21-38. doi: 10.3114/sim.2008.61.02

Zhang, G., Shoham, D., Gilichinsky, D., Davydov, S., Castello, J. D., and Rogers, S. O. (2006). Evidence of influenza A Virus RNA in Siberian Lake Ice. J. Virol. 80, 12229-12235. doi: 10.1128/JVI.00986-06

Conflict of Interest Statement: The author declares that the research was conducted in the absence of any commercial or financial relationships that could be construed as a potential conflict of interest.

Copyright $(2015$ Edwards. This is an open-access article distributed under the terms of the Creative Commons Attribution License (CC BY). The use, distribution or reproduction in other forums is permitted, provided the original author(s) or licensor are credited and that the original publication in this journal is cited, in accordance with accepted academic practice. No use, distribution or reproduction is permitted which does not comply with these terms. 